\title{
LETTERS FROM NURSES IN FOREIGN SERVICE
}

I.

Dear Editor: You may be glad to know the interest of the nurses over here. Today when the Metro had stopped and it was almost impossible to get a taxi. one nurse walked for an hour and forty-five minutes, then by the help of two French officers managed to get a taxi for eight francs for the rest of the way (ordinarily the fare would have been about $1 \mathrm{fr} .50$ ), and another nurse walked for two hours in order that the babies might not miss their feedings. It was the only way they could reach their milk stations. We are just finishing a two months' intensive course on child hygiene for our visiteuses d'Enfant who are to be sent out under the direction of the American nurses to assist in the campaign against infant mortality. Another course is to be started in Lyons in April. In our department, a branch of the Children's Bureau took care of 1731 patients last week, 110 of them being in the hospital and 523 refugees. In another hospital there were 112 patients. With the lack of doctors, the crowding together in many places, and the lack of control, you can readily imagine what the danger from contagious diseases would be and how valuable is the guidance of the public health nurse. From Blois the doctor writes that many of the infants are "like dried up old men and women, the sight is heart-breaking." You may be interested in knowing that the nurses in Paris were able to give assistance to the refugees who were evacuated from Noyon, Arras, Amiens and Compiègne. After this last big drive there were thousands of them who were sent through Paris. How many we do not know yet. I will tell you what happened in one station where I had charge the second night. At eight o'clock there were a few hundred of them at the station, which is used as a canteen, and it seemed very quiet. At nine, on trains from the north, arrived the old, the sick, the lame, with their big bundles, dogs, cats, chickens,-all of their earthly possessions in their hands. Between nine at night and nine the next morning, 5000 people went through this station. They slept on the floor and they sat on the benches. I never heard one complaint, not even when our food gave out, and for a time we had no bread to give them. However, we were able, before they started, to give them a hot drink and some food. As the station was overflowed a cinema which is near the station was opened, and later, the Y. M. C. A. opened its place for a hundred refugees. Ambulance men were there to meet the wounded soldiers and take them to the hospitals, and between trains, thy transferred these hundred people to the Y. M. C. A. hotel, which is near the station. The Red Cross and all the other organizations had soon organized themselves into a group to take care of the refugees as they passed through Paris. French people, of course, are always sympathetic and kind to them. The sight of tiny babies and old people, with no member to help them, leaving all they have behind them, is one which is never to be forgotten. We are glad we were here to help just a little bit, and I thought you might like to know that the nurses were able to give some assistance.

$$
\text { Paris }
$$

H. L. L.

II.

Dear Editor: It is indeed a busy, busy time these days in the midst of the big battle that is going on. When you realize that it is in progress about the same distance away from us as Princeton is from Philadelphia, you will understand what our work must be. The outcome of the battle will mean much to us here. We eagerly read the Communique each day and wonder the rest of the day what is doing. Possibly you at home in the States know more than we do who are so close. The soldiers are wonderful, though, and make us ashamed of ever 
complaining as we sometimes do. I just wish you could see some of the big wounds they have and never a grumble or a groan, they just smoke and smoke and joke with us. It has taught us a big lesson, if we only take it to heart. We are looking forward to the first number of the JourNaL.

France

M. D.

\section{HISTORY OF NURSING}

Dear Editor: We have emphasized strongly the need of organization and organized effect. May we not wisely emphasize for some time to come, the responsibility of the individual nurse in bringing about the new spirit that is needed?

One of the greatest needs of our system of nurse education is more teaching of the History of Nursing.

If it is important that our normal schools teach History of Education to imbue teachers with high ideals of Pestalozzi, Arnold of Rugby and Horace Mann, does not the nurse need in fully as large a degree the inspirations and ideals to be gained from a knowledge of those noble women of the Society of Friends, Elizabeth Fry, Florence Nightingale, the Angel of the Crimea, and our own Clara Rarton?

Many pupil nurses become disatisfied as soon as they are put on night duty, and many drop out of training at that time. May it not be that night duty would not seem so hard if those young nurses had their first enthusiasm sustained in the early trying experiences of hospital life by the vision of Florence Nightingale as she quietly ministered to those uncounted thousands in the Crimea?

Let us make our nurses familiar with the History of Nursing early in the course of training, at that impressionable period when their highest ideals take form.

Let the History of Nursing be brief enough to be used as a textbook and inclusive enough to give the nurse a realization that she is a part of the noble band of the world's workers, and that her calling has a dignity which she will want to help uphold.

I would not urge the over-education of nurses, but I wonder if we do not sometimes put too much stress on non-essentials and forever miss instilling into our pupils the larger world vision that will enable them to realize the import of the words of our Divine Master when He said, "For even the son of man come not to be ministered unto but to minister."

SR. MARY JOAN. 